\title{
Spanish in the United States as an Example of the Interaction between Language, Politics and Ethnicity
}

\author{
Purity Ada Uchechukwu \\ DOI: http://dx.doi.org/10.4314/ujah.v12i1.10
}

\section{Abstract}

The continuous influx of immigrants from Spanish-speaking countries and the concentration of Hispanics/Latinos in certain areas in the United States, all contribute to the use and expansion of the Spanish language in America. Nevertheless, Spanish appears not to be making much impact as would be expected. The reasons for this can be traced to the language politics of the United States, strongly represented in the efforts of the Anti-bilingual Education proponents who, through Pro-English Organisations, have secured to a large extent, the marginalisation of the language of this ethnic group. In addition, the Americanization of the country is a cultural factor which upholds the hegemony of the English language as a standard of American culture and identity. This paper looks at the politics behind the linguistic situation in the United States with particular focus on the interaction of language, politics and ethnicity and its effects on Hispanic identity.

\section{Introduction}

This work is divided into seven sections. The second section presents the relationship of ethnicity to language. This will be followed in section three by a brief historical overview of the linguistic situation in the Americas before colonisation. A statistical representation of the Hispanics and their distribution in the United States takes up section 4. Section 5 gives an insight into the language politics of the USA, and the proponents of English-Only legislations. Section six 
explores the impact of these policies on Hispanic identity. Section seven forms the summary and conclusion.

\section{The Relation of Ethnicity to Language}

People of Hispanic origin are those who indicate their origin to be Mexican, Puerto Rican, Cuban, Central or South American, or some other Hispanic origin. People of Hispanic origin may be of any race (Goldman Sachs Strategy Research, 2007, p. 4). However, the terms Hispanic and Latino are used interchangeably by the people themselves (those in California and Chicago generally prefer Latino, in Florida and Texas, the label, Hispanic is more appreciated), though the majority do not identify themselves with either of these terms. Instead, they identify themselves, with their Latin-American countries of origin. Thus, they would rather say, "I'm Mexican", "I'm Cuban", etc. However, to present a united front in order to sustain their power on political, economic, civil rights matters and education, an official, unifying category under one name (or two), in the form of Hispanics or Latinos is used (Ramos, 2004, as cited in Goldman Sachs Strategy Research, 2007, p. 22; see also MarMolinero, 2000, p. 179).

On the other hand, if language is taken to be a powerful symbol of national and ethnic identity (Spolsky, 1999, p. 181), and the Latinos in the United States go beyond their countries of origin to use an aspect of their language to identify themselves it naturally follows that the Spanish language forms part of their consciousness, and "to relinquish Spanish either literally or symbolically is to relinquish a significant and powerful dimension of personal and social identity" (Johnson, 2000, p. 177). This is corroborated in the words of Anzaldúa, who categorises ethnic identity as a "twin skin' to linguistic identity, and says, "I am my language" (Anzaldúa, 1987, as cited in Gibson, 2004, p. 4). 
This relationship of language and ethnicity to politics is best examined from a historical perspective: the period of Spanish colonial expansion in the Americas.

\section{The Linguistic Situation in America before Colonisation}

While the Unites States of America as it is known today demographically covers regions that were formerly part of the Spanish expansion in the Americas, linguistically, the United States was never homogeneous at any point in its history (Schmid, 2001, p. 10). The Native American Indians had over three hundred languages before the arrival of the first Europeans (Dicker, 1996, p. 40), and distinguished themselves in line with the level of their development. The Aztecs, Maya and Inca had developed a high culture; the Taínos in the Antilles had a farming culture, while the ethnic groups in the Amazons were mostly hunters and collectors (Noll, 2001, p. 58). The three major colonial powers that penetrated these peoples and almost extinguished their native languages and culture were the Spanish, the English and the French.

\section{The Arrival of the Europeans}

The Spanish Conquistador, Juan Ponce de León (1406-1502) founded Caparra (later San Juan, capital of Puerto Rico) as the first Spanish settlement in Puerto Rico in 1508. Five years later, he landed as the first European in Florida. After several unfruitful efforts at Colonisation, he fled to Cuba, where he later died. In 1517 the first Spaniards reached Yucatan in Mexico and the Spanish expansion progressed throughout the South-western states, culminating in the purchase of French Louisiana in 1763.

Political upheavals forced France to sell off Louisiana (Louisiana Purchase) to the United States in 1803. Spain handed over Florida to the USA in 1891, and Mexico won its 
independence from Spain in 1821. Texas became independent of Mexico in 1836 and in 1845 was occupied by the United States of America, leading to the MexicanAmerican war (1846-1848). The end of this war and the signing of the peace accord (Guadalupe Hidalgo) meant that Mexico lost half of its original territory, which comprised of California, Nevada, Utah, Arizona, Colorado, New Mexico, as well as the regions of Wyoming, Kansas and Oklahoma to the United States (Noll, 2001, p. 99). Spain lost the Philippines, Guam, Hawaii and Puerto Rico to the USA at the end of the Spanish-American war in 1898.

At the end of the Second World War, the AngloAmericans or English-settlers became the majority ethnic group in America. On the other hand, and although Cubans have lived in Florida since the $19^{\text {th }}$ century, the US state of Miami experienced an upsurge of Cuban immigrants (both legal and illegal) after the Cuban revolution of 1959. Meanwhile, the search for a better life and escape from poverty drove many Mexicans to the United States, while civil wars made Latinos in Nicaragua and El Salvador seek for reprieve also in America. The effect of these new arrivals was an increase in the population of the Hispanics and the spread in the use of the Spanish language, especially in the South-western states.

Meanwhile, and as far back as 1885 , almost forty years after the Anglo-Saxon's occupation of the South-western states, the population of the Hispanics in the region rose to 100,000 as against 40,000 of the English-settlers (Espinosa, 1975 , p. 100). The use of Spanish was upheld by the Hispanics and the Spanish language was placed on the same level as its English counterpart. This was backed up by the drafting of the first constitution of California in Spanish and English. Nevertheless, with the rise in the Latino population, the English-settlers decided to sponsor the hegemony of the 
English language. This took the form of a law, promulgated in 1894, which stipulated that only persons with knowledge of the English language were eligible to vote (Espinosa, 1975, p. 100; Azevedo, 2005, p. 377). As a consequence, the laws and customs were adapted to the English language to the disadvantage of the Spanish language and culture.

In recent times, however, the Hispanic population constitutes the highest minority group in the United States, and unlike the case of previous immigrants, are able to uphold their culture and language. The conditions that favour this trend are examined below.

\section{Hispanic Population Growth}

\section{Percent Distribution of Hispanics by Type: 2002}

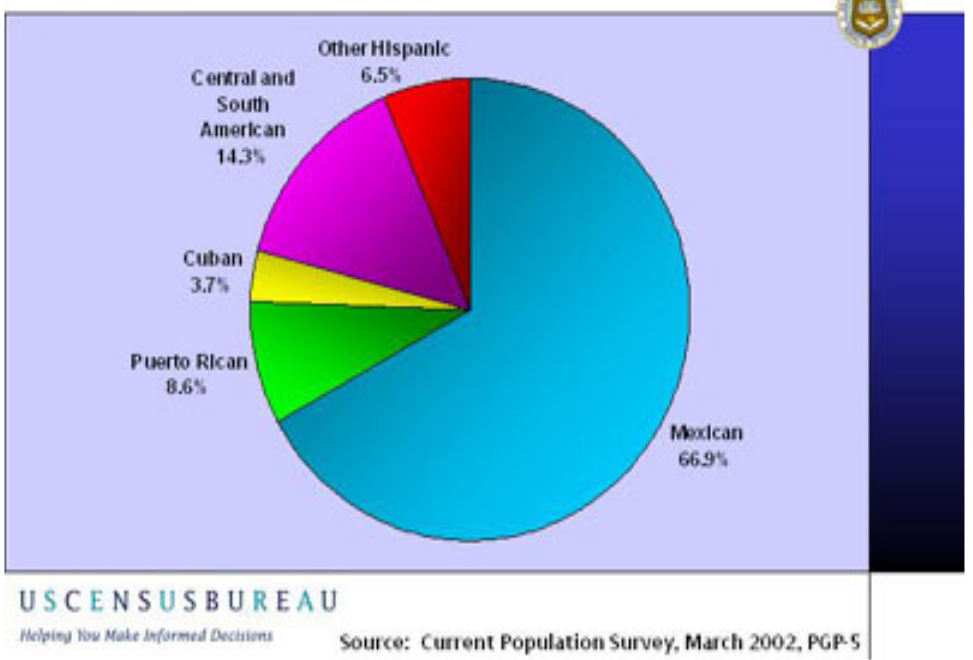

From the USCENSUSBUREAU above, it can be seen that the Hispanics as at 2002, with a population of 37.4 162 
million made up the highest minority group in the United States of America. The percentage from Mexico made up $66,9 \%$, followed by the Puertoricans with $8,6 \%$ and the Cubans as the smallest minority group with 3,7\%. There are also other groups of Latinos from Spain and Latin-American regions in Middle and South America with a total percentage population that make up $14,3 \%$. The exact number of Hispanics living in the USA might be difficult to approximate because of illegal immigration. Nonetheless, the majority of Hispanics living in the USA today are born there, and Spanish has become after English, the most spoken language, making the US the country with the second highest number of Spanish speakers in the world, surpassed only by Mexico (Ruiz Mantilla, 2008).

Projections from the US Census Bureau and Goldman Sachs Strategy Research (2007, p. 5) indicate that roughly half of US population growth over the next three years will come from the Hispanic community. This steady rise in population and the consequent spread in the use of the Spanish language have not gone unnoticed over the years; in fact, as will be seen in the next section, it has become the source of political reactions within the US, with language taking the centre stage.

\section{The Politics of Language in the United States}

The United States does not have a legislation which states that English is the official language of the Union (Stewart, 1999, p. 7). All the same, language politics in the Unites States has been summarised as "a situation where the white Anglo-Saxon Protestant dominant culture assumes a neutral position as a unifying civic culture while all other cultures are seen as 'ethnic' and therefore divisive" (Schmid, 2001, as cited in Richmond, 2001, p. 68; see also Huntington, 2004a, p. xvii). The legitimacy of this statement is confirmed in the 
on-going language issue in America, the roots of which date back to the period of the Spanish colonial expansion and arrival of the English-settlers in the South-western states.

Furthermore, bilingualism has become a controversial issue in the US even though the Bilingual Act was approved in 1968 and involves giving assistance to schools that served linguistic minorities. In recent times however, bilingualism in the majority of the states in the US has suffered setbacks. Now, various forms of Official English state legislations that demand that the English language be the only official language in America and language of instruction in public schools have been adopted. Where this law has scaled through, public funds for the promotion of minority languages have been scrapped. Behind these legislative laws are Pro-English Organisations such as US English, English First and English Only, who openly object to public use of Spanish and other minority languages in the American society. The ideology and apparent successes of these organisations are highlighted in the next sub-section.

\section{The Ideology and "Success" of the Pro-English Organisations}

When language politics involves an attempt to consciously influence a speaker through prohibition or regulation of certain words and expressions (Metzler Lexikon Sprache, 2000, p. 668), then the Pro-English Organisations can be said to already be playing such politics in thirty states in the United States of America.

Going back to the history of immigration to the US, the country experienced a sharp rise in immigration nearly twice as fast in the 1970 s as in the 1980s, with a significant proportion of these new immigrants Spanish speaking. This situation fuelled the belief that newcomers no longer learn English, giving rapid rise to organisations such as US 
English, English Only and English First in the 1980s (Schmid, 2001, as cited in Richmond, 2001, p. 70).

The proponents of Official English base their stand on "linguistic homogeneity in the development of American nationalism and national identity" (Schmid, 2001, as cited in Richmond, 2001, p. 70). Based on this argument, the aim of these organisations is the enshrinement of English as the only official national language, and the elimination of bilingualism in America.

The apparent successes of these organisations are visible in the reversal of bilingual laws and the imposition of Official English legislative laws in several states in the US. For example, although in 1994 a Federal Tribunal ruling in Arizona turned down the demand of this group which sought to prohibit the use of Spanish at the workplace; this state has now adopted Anti-bilingual law. Also, San Antonio in the state of Texas has reversed its bilingual law which it introduced in 1995. The greatest success for these organisations to date is perhaps, the case of California. This state with the highest number of Hispanics and with a bilingual law dating as far back as 1894 passed Proposition 227 otherwise known as Anti-bilingual Education law in 1998. The situation in this state is such that only the English language is allowed as the language of instruction in schools. So far, thirty states have followed suit, making the English language official, while twenty-eight states still have laws pending. Figure 2 below is an illustration of the US states that have adopted English as their official language. 


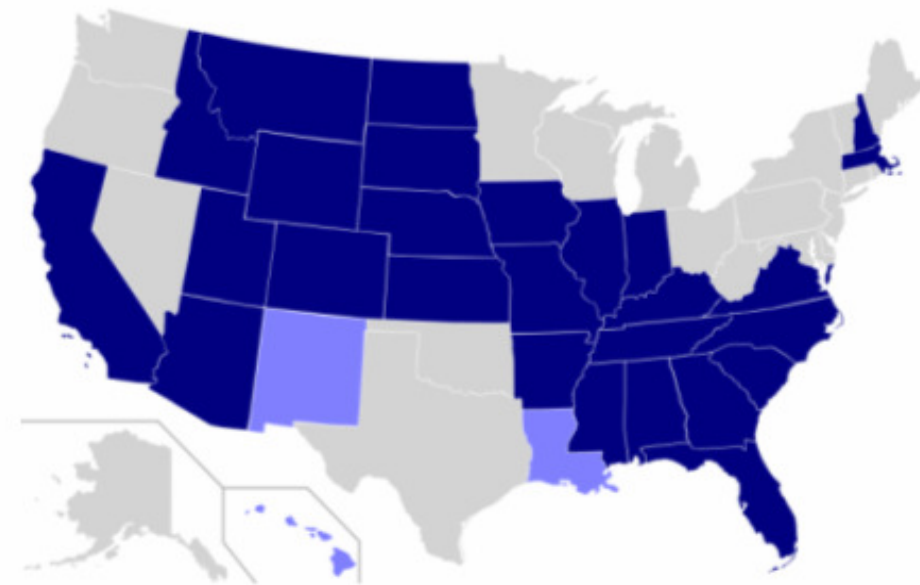

Figure 2. US States in which English is official language by Legislation

(Vector map from Image.Blank US map.svg by User.Theshibboleth

The dark coloured states have adopted Official English legislative laws and eliminated bilingual education laws. The gray coloured states still retain bilingual laws, while the remaining states of Texas, Oregon, Washington, Oklahoma and some in the north-eastern part of the US will soon promulgate the Official English laws. The subsequent effect of the politicising of language on Latino identity and culture is discussed in the next section.

\section{The Philosophy of Americanization and Hispanic Identity}

In the early years of the Republic, language was considered an individual matter for white immigrants so long as they did not threaten the dominant elite (Schmid, 2001, as cited in Richmond, 2001, p.70). In addition, conquered ethnic groups were never allowed the freedom to maintain their languages, and in the words of Huntington, "the U.S. Founding Fathers considered the dispersion of immigrants essential to their assimilation" (2004b). This is confirmed considering the current polarisation in language matters in the United States, 
whose origin can be traced in part to the philosophy of Americanization.

The philosophy of Americanization was introduced in Puerto Rico after its invasion by the United States in 1898. This ideology of the then President of Puerto Rico, Theodore Roosevelt (1901-1909), stipulates that:

The man who becomes completely Americanized... and who talks United States instead of the dialect of the country which he has of his own free will abandoned is not only doing his plain duty by his adopted land, but is also rendering himself a service of immeasurable value. (Zentella, 1997a, p. 266)

This ideology of Americanization equates true patriotism with true Americanism, and places the lack of knowledge of (American) English on the same footing as being unpatriotic. This implies giving up one's ethnic identity, language and culture in order to be fully assimilated into the American society. This forced monolingual proved a failure in Puerto Rico.

Fact is that the United States has existed for approximately 200 years without any formal declaration of an official language (Schmid, 2001, as cited in Richmond, 2002 p. 70). This is probably because there is no need to apply an official stamp to the linguistic situation based on certain facts in the United States which speak for themselves.

First of all, the English language is the most widely used lingua franca in America and will remain so in the future. This is because the Spanish language finds itself in a permanent diglossie situation with its English counterpart, and consequently continues to occupy a subordinate position. This is especially predominant in the major and big cities, 
where the number of Hispanics equals the number of Americans. A situation described by Mendieta (1999) as follows:
el uso del español decrece rápidamente en todas las regiones entre los emigrantes de segunda y tercera generación, independientemente del grupo. Nueve de cada diez hispanos nacidos fuera de los EE.UU. hablan español en el hogar, frente sólo cinco de cada diez en el grupo de los nacidos en los EE.UU. (p. 89)

Independent of the group, the use of Spanish among immigrant children of the second and third generation of Spanish immigrants is on the decline in all the regions. While nine out of every ten Hispanic born outside the United States speak Spanish at home, only five out of every ten born within the United States can speak the language.

This decrease in the use of the language among the young generation of Latinos is compounded by the phenomenon of codeswitching: an indirect adoption and integration of Anglicism in the spoken Spanish of young Hispanics. This has given rise to Spanglish, the effect of which is twofold. To the outsider, codeswitching is evidence of a lack of proficiency in the English language (Zentella, 2002), while to the Latinos who speak Spanglish, it is a representation of their identity, as reflected in the words, "Spanglish is what we speak, but it is also who we Latinos are, and how we act, and how we perceive the world" (Morales, 2002, p. 3).

Thirdly, the philosophy of Americanization still records great success especially among the youth and the Hispanic middle-class, who want to be identified as patriotic 
Americans. This is expressed in the adoption of the typical American speech, customs and culture.

Another key area where Latino identity is gradually losing its presence is in the workplace in America. As Gibson (2004, p. 6) points out, English-Only policies attempt to dictate the identity of workers in order to exercise control and remake the workers in the image of the English speaking employer.

In view of the above, the reactions of the English-Only organisations and voices such as Huntington (2004b) have been described as a form of 'hispanophobia' (Zentella, 1997b; Mar-Molinero, 2000, p. 179) and a case of majority language speakers feeling threatened (Mar-Molinero, 2000, p. 163).

\section{Conclusion}

An end is not in sight to the increase in the number of Hispanics in the United States of America. Even attempts by many states such as Arizona to curb illegal immigration through legal jurisdiction are being contested in the American law courts.

In the long run the immigration volume and regional concentration of the Hispanics in America might prove the most favourable factors for retaining Hispanic cultural identity, especially among the young generation of Latinos despite all opposition and politicising of the language issue. This growing trend viewed from an economic perspective is already coined as the hispanization of the United States (Goldman Sachs Strategy Research 2007). 


\section{References}

Azevedo, M. (2005). Introducción a la lingüística española. USA: Pearson Education, Inc. New Jersey.

Espinosa, A. Jr. (1975). Problemas Lexicográficos del

Español del Südoeste. In. El lenguaje de los Chicanos.

Regional and Social Characteristics Used by Mexican

Americans. (pp. 3-18). Virginia. USA: Center for Applied

Linguistics.

Cabeza de la Vaca, A. (1944). Naufragios y comentarios.

Madrid: Espasa-Calpe.

Dicker, S.J. (1996). Languages In America. A Pluralist View

Bilingual Education and Bilingualism. United States: 10.

Multilingual Matters Ltd.

English First (n.d.). Retrieved from: http://englishfirst.org/.

Gibson, K. (2004). English only court Cases involving the

U.S. Workplace: The Myths of Language Use and the

Homogenization of Bilingual Workers' Identities. Second

Language Studies, 22(2), 1-60.

Goldman, Sachs. Strategy Research (2007). The Goldman Sachs Group, Inc.

Huntington, S. P. (2004a). The Hispanic challenge

[Electronic version]. Foreign policy. Retrieved from

http://www.foreignpolicy.com/story/cms.php?story_id=2 495 on $3 / 11 / 04$.

Huntington, S. P. (2004b). Who Are We? The Challenges to America's National Identity. New York: Simon and Schuster.

Johnson, F. L. (2000). Speaking culturally: Language diversity in the United States. Thousand Oaks, CA: Sage Publications.

Mar-Molinero, C. (2000). The politics of language in the Spanish-speaking world. London: Routledge. 
Mendieta, E. (1999). El préstamo en el español de los Estados Unidos. Studies in Ethnolinguistics; Vol 1. New York: Peter Lang Publishing.

Morales, E. (2002). Living in Spanglish: A search for Latino identity in America. New York: St. Martin's Press.

Metzler Lexikon Sprache (2000). H. Glück, (Hrsg.) Stuttgart: Verlag J.B. Metzler.

Noll, V. (2001). Das amerikanische Spanisch. Ein regionaler und historischer Überblick. Tübingen: Max Niemeyer Verlag $\mathrm{GmbH}$.

Richmond, C. C. (2001, December). The Politics of Language and Ethnicity. [Review of the book The Politics of Language: Conflict, Identity and Cultural Pluralism in Comparative Perspective]. The Global Review of Ethnopolitics, Vol. 1, no. 2, 67-73.

Ruiz Mantilla, J. (2008, October 16). Más speak Spanish que en España. El País. Retrieved from http://www.elpais.com/articulo/cultura/speak/spanish/ Espana/elpepucul/20081006elpepicul_1/Tes.

Spolsky, B. (1999). Second-language learning. In J. Fishman (Ed.), Handbook of language and ethnic identity (pp. 181192). Oxford: Oxford University Press.

Stewart, M. (1999). The Spanish Language Today. London: Routledge. U.S. Census Bureau (2002). Percentage Distribution of Hispanics by Type. Washington, D.C.: U.S. Government Printing Office.

US Only (n.d.). US Only laws. Retrieved from: http://www.us-english.org/view/19.

Zentella, A. C. (1997a). Growing Up Bilingual. Puerto Rican Children in New York. Massachusetts: Blackwell Publishers. 
Zentella, A. C. (1997b). The Hispanophobia of the Official English Movement in the U.S. International Journal of the Sociology of Language, 127, 71-86.

Zentella, A. C. (2002). Latin languages and identities. In M. M. Suárez-Orozco \& M. M. Páez (Eds.), Latinos: Remaking America (pp. 321-338). Berkeley: University of California Press. 